\title{
Формирования InAs островков на поверхности InP(001) при высокотемпературном отжиге в потоке мышьяка
}

\author{
Д.А. Колосовский, Д.В. Дмитриев, С.А. Пономарев, А.И. Торопов, К.С. Журавлев \\ Институт физики полупроводников им. А.В. Ржанова, Новосибирск, 630090, Лаврентьева 13 \\ тел:+7 (913) 954-5584, эл. почта: danil-ak@yandex.ru
}

DOI $10.34077 /$ RCSP2021-98

Подложки $\mathrm{InP}(001)$ используют для создания гетероэпитаксиальных структур (ГЭС), на основе которых изготавливают транзисторы с высокой подвижностью электронов, лазеры, электрооптические модуляторы и фотодиоды [1]. Рост гетероструктуры начинается с удаления аморфного окисного слоя подложки. Обычно окисный слой на подложке InP удаляют высокотемпературным отжигом в потоке As. Однако в процессе отжига происходит изменение элементного состава поверхности подложки с образование твердого раствора InPAs и островков InAs [2, 3]. Решеточное рассогласование между InP и InAs приводит к возникновению напряжений и центрам зарождения дефектов в ГЭС [4], что влечет изменения в начальных этапах зародышеобразования и последующих процессах эпитаксиального роста. Поэтому целью работы является исследование процесса формирования InAs островков на поверхности $\operatorname{InP}(001)$ в процессе высокотемпературного отжига в потоке мышьяка.

В работе использовались ерi-ready подложки $\mathrm{InP}(001)$ фирмы AXT. Отжиг проводился в ростовой камере установки молекулярно-лучевой эпитаксии Riber Compact 21T. Температура отжига варьировалась от $480-540{ }^{\circ} \mathrm{C}$, а поток мышьяка изменялся от $8 \times 10^{-6}$ Торр до $2.5 \times 10^{-5}$ Торр. Отжиг завершался формированием структуры $(4 \times 2)$ на дифракционной картине. Морфологию поверхности образцов исследовали методом атомно-силовой микроскопии (АСM) на микроскопе Solver Smena$\mathrm{P} 47 \mathrm{H}$.

В работе наблюдается экспоненциальный рост плотности InAs островков от $4.4 \times 10^{7} \mathrm{~cm}^{-2}$ до $1.8 \times 10^{8}$ $\mathrm{cm}^{-2}$ при повышении температуры отжига и потока мышьяка. Островки вытянуты вдоль направления $\left[\begin{array}{lll}1 & \overline{1} & 0\end{array}\right]$ и имеют латеральный размер от 65 нм до 130 нм вдоль этого направления. Латеральный размер InAs островков вдоль направления [lll $\left.1 \begin{array}{ll}1 & 0\end{array}\right]$ составляет от 40 нм до 90 нм. Суммарная площадь поверхности, занимаемая InAs островками, не превышает 1.5\% от площади подложки. Повышение температуры отжига приводит к более равномерному распределению InAs островков по поверхности. Наименьшая плотность островков и занимаемая ими площадь наблюдались при температуре отжига $480{ }^{\circ} \mathrm{C}$ и потоке мышьяка $8 \times 10^{-6}$ Tорр.

Причиной появления этих островков является десорбция фосфора и сегрегация индия т.к. температура отжига подложки выше температуры диссоциации поверхности $\operatorname{InP}$ [5]. В результате на поверхности образуются избыточная концентрация адатомов индия, которые мигрируют по поверхности. В изломе моноатомной ступени наименьшая энергия связи и встраивание в излом адатомов, находящихся на расстоянии длины диффузии от излома моноатомной ступени, наиболее вероятно [6]. В итоге в излом моноатомной ступени встраиваются адатомы индия и мышьяка, в потоке которого происходит процесс отжига. В результате образуется InAs зародыш, который разрастается.

В работе экспериментально получены условия отжига подложки $\operatorname{InP}(001)$ с наименьшей плотностью островков, что позволяет выращивать ГЭС для СВЧ фотодиодов и электрооптических модуляторов Маха-Цендера с минимальной плотностью дефектов.

АСМ исследования проводились на оборудовании ЦКП наноструктуры.

\section{Лumepamypa}

[1] Jesus A. del Alamo // Nature. 2011. V 479. P.317-323.

[2] Д.В. Дмитриев и др. // ФТП. 2021. Т. 55, вып. 10. С. 877-881.

[3] D.V. Dmitriev et al. // Surface Science. 2021. V. 710. P. 121861.

[4] F. Peiro et al. // Applied Surface Science. 1993. V. 65. P. 447-454

[5] S. Kanjanachuchai et al. //Applied Surface Science. 2021. V. 542. P. 148549.

[6] W. K. Burton et al. // Phil. Trans. Roy. Soc. 1951. V 243, P 299. 